\title{
Keberlakuan Produk Hukum Daerah Tanpa Prosedur Fasilitasi dalam Pembentukan Peraturan Daerah
}

\author{
The Aplication of Regional Legal Products Without Facilitation Procedures \\ in the Fomation of Regional Regulations
}

\author{
Muhammad Hasan \\ Biro Hukum Setda Prov. Sultra \\ E-mail: hasanbirohukum@gmail.com \\ La Sensu \\ Pascasarjana Universitas Halu Oleo \\ E-mail: lasensu_march72@yahoo.com \\ Kamaruddin Jafar \\ Pascasarjana Universitas Halu Oleo \\ E-mail: Kamaruddinjafar88@gmail.com
}

\begin{abstract}
This research focused on the validity of regional legal products without facilitation prosedures in the formation of regional regulations. validity of legal products is related to the formation of regional regulations in districts/cities without the procedure offacilitation to the Governor in the formation of regional Regulations. Therefore this study focuses on the problem as follows :1.can the draft Regional Regulation (Ranperda) without facilitation procedures in the formation of regional legal products be implemented? 2. How is the legal position of the facilitation fuction in the establishment of Regency/City Regional Regulation legal products?

This research is normative legal research namely seeing the validity by answering, analyzing, analyzing the application of legal products. Research based on positive legal inventories, research on legal principles and inconcreto legal research, the approach used is a noemative juridicial approach the normative juridical approach is the approach taken by studying the law, theoretical theory and concept-concepts related to the problems to be studied.

This study uses primary legal materials, namely legal material that is closely related to the problems to be studied which includes legislation and secondary legal materials that provide an explanation of primary legal materials, including documents, books, papers, research reports, and other legal materials that relevant to this research material.

Based on the research conducted, the results of the study show that the draft Regional Regulation without facilitation procedures in establishing reginal legal products is
\end{abstract}


not in accordance with the provisions of the legislations as intended. In law number 23 of 2014 concerning regional government. So that in the formulation of regional regulations, the facilitation procedure must be passed as a guideline in the drafting of regional regulation draft number before being determined by the Regional Head and promulgated by the Regional secretary and legal consequences/facilitation procedures without formation Regulations The region is null and void because it violates the procedure for granting the Regional Registry Design Number as stipulated in Minister of Home Affairs Regulations Number 80 of 2015 as a guideline in granting nomor darft register Regional Regulation.

Keyword: legal products, facilitation, establishment of regional regulations

Abstrak: Penelitian ini difokuskan pada keberlakuan produk hukum daerah tanpa prosedur fasilitasi dalam pembentukan peraturan daerah. keberlakuan produk hukum daerah berkaitan dengan pembentukan Peraturan Daerah di Kabupaten/Kota tanpa prosedur fasilitasi ke Gubernur dalam pembentukan Peraturan Daerah. Oleh karena itu, penelitian ini memfokuskan pada masalah sebagai berikut: 1. Apakah rancangan peraturan daerah (ranperda) tanpa prosedur fasilitasi dalam pembentukan produk hukum daerah dapat diberlakukan? 2. Bagaimana kedudukan hukum fungsi fasilitasi dalam pembentukan produk hukum peraturan daerah kabupaten/kota?

Penelitian ini adalah penelitian hukum normatif, yaitu melihat keberlakuan dengan menjawab, menganalisis keberlakuan produk hukum daerah terhadap fasilitasi dalam pembentukan peraturan daerah. Penelitian yang berbasis pada inventarisasi hukum positif, penelitian terhadap asas-asas hukum, dan penelitian hukum inconcreto. Pendekatan yang digunakan adalah pendekatan secara yuridis normatif. Pendekatan secara yuridis normatif adalah pendekatan yang dilakukan dengan cara mempelajari perundang-undangan, teori-teori dan konsep-konsep yang berhubungan dengan permasalahan yang akan diteliti.

Penelitian ini menggunakan bahan hukum primer, yaitu bahan hukum yang erat kaitannya dengan permasalahan yang akan diteliti yang meliputi peraturan perundang-undangan dan bahan hukum sekunder yang memberikan penjelasan mengenai bahan hukum primer, meliputi dokumen, buku, makalah, laporan penelitian, serta bahan hukum lainnya yang relevan dengan materi penelitian ini.

Berdasarkan penelitian yang dilakukan, hasil penelitian menunjukkan bahwa rancangan Perda tanpa prosedur fasilitasi dalam pembentukan produk hukum daerah tidak sesuai dengan ketentuan peraturan perundang-undangan dalam hal ini UU No. 23 Tahun 2014, karena prosedur fasilitasi merupakan bagian dari prosedur dalam pembentukan rancangan Perda sebagaimana dimaksud dalam UU No. 23 Tahun 2014. Sehingga dalam pembentukan rancangan Perda harus melewati prosedur fasilitasi sebagai pedoman dalam pemberian nomor register rancangan Perda sebelum ditetapkan oleh Kepala Daerah dan diundangkan oleh Sekretaris Daerah dan dampak/akibat hukum tanpa prosedur fasilitasi dalam pembentukan Perda adalah batal demi hukum karena melanggar prosedur pemberian nomor register rancangan Perda sebagaimana diatur dalam UU No. 23 Tahun 2014 yang mencakup pula prosedur fasilitasi yang diatur dalam Permendagri No. 80 Tahun 2015 sebagai pedoman dalam pemberian nomor register rancangan Perda.

Kata kunci: Produk Hukum; Fasilitasi; Pembentukan Peraturan Daerah 


\section{PENDAHULUAN}

Negara Kesatuan Republik Indonesia (NKRI) adalah negara berbentuk kesatuan yang berarti dalam penyelenggaraan pemerintahan negara dibentuk pemerintahan nasional yang berada pada Pemerintah Pusat. Untuk melaksanakan kekuasaan pemerintahan negara di seluruh wilayah dibentuk pemerintahan daerah. Wewenang untuk mengatur dan mengurus segala bentuk kepentingan masyarakat menurut prakarsa sendiri berdasarkan aspirasi masyarakat adalah wujud adanya otonomi dalam penyelenggaraan pemerintahan daerah. Karena otonomi menurut Bagir Manan, adalah kemandirian untuk mengatur dan mengurus urusan (rumah tangganya) sendiri. ${ }^{1}$

Penyelenggaraan pemerintahan daerah untuk menjalankan otonomi daerah sebagai pelaksanaan asas desentralisasi telah diterima sebagai suatu hal yang bersifat universal dan dalam rangka mewujudkan sebagaimana diuraikan dalam paragraf tersebut di atas, maka Undang-Undang Dasar Negara Republik Indonesia Tahun 1945 (UUDNRI Tahun 1945) telah memberikan kewenangan yang seluas-luasnya kepada Daerah sebagaimana tertuang dalam Pasal 18 UUDNRI Tahun 1945.

Otonomi mengandung arti kemandirian untuk mengatur dan mengurus urusan rumah tangganya sendiri. Kewenangan yang diberikan oleh Pemerintah Pusat kepada Daerah merupakan peluang untuk meningkatkan pertumbuhan perekonomian Daerah melalui pengelolaan potensi ekonomi yang dimilikinya, dan keuntungan-keuntungan lain yang bisa didapatkan melalui otonomi daerah. Dalam rangka pengelolaan urusan yang menjadi kewenangan otonomi dalam penyelenggaraan pemerintahan, pemerintahan daerah berhak menetapkan Peraturan Daerah (Perda).

Ketentuan Pasal 18 ayat (6) UUDNRI Tahun 1945 menegaskan, bahwa "pemerintahan daerah berhak menetapkan peraturan daerah dan peraturan-peraturan lain untuk melaksanakan otonomi dan tugas pembantuan."2 Ini berarti bahwa penetapan Perda merupakan hak bagi Daerah yang secara atributif diberikan oleh konstitusi dalam rangka menyelenggarakan pemerintahan daerah untuk melaksanakan otonomi daerah.

Pasal 242 ayat (4) UU No. 23 Tahun 2004 menegaskan, "Bupati/Wali Kota wajib menyampaikan rancangan Perda Kabupaten/Kota sebagaimana dimaksud pada ayat (2) kepada Gubernur sebagai wakil Pemerintah Pusat paling lama 3 (tiga) hari terhitung sejak

1 Bagir Manan, Hubungan Antara Pusat dan Daerah Menurut UUD 1945, Jakarta: Pustaka Sinar Harapan, 1994, hlm. 21.

2 Pasal 18 ayat (6) Undang-Undang Dasar Negara Republik Indonesia Tahun 1945 Perubahan kedua 18 Agustus 2000. 
menerima rancangan Perda Kabupaten/Kota dari pimpinan DPRD Kabupaten/Kota untuk mendapatkan nomor register Perda." Ketentuan ini mewajibkan kepada kepala daerah Kabupaten/Kota untuk tidak langsung menetapkan Perda dengan cara menandatangani sebelum mendapatkan nomor register dari Gubernur.

Bahkan Pasal 243 ayat (1) UU No. 23 Tahun 2014 dengan tegas mengatur, bahwa "rancangan Perda yang belum mendapat nomor register sebagaimana dimaksud dalam Pasal 242 ayat (5) belum dapat ditetapkan kepala daerah dan belum dapat diundangkan dalam lembaran daerah." Untuk melaksanakan lebih lanjut ketentuan Perda, Pasal 246 ayat (1) UU No. 23 Tahun 2014 menegaskan, bahwa "untuk melaksanakan Perda atau atas kuasa peraturan perundang-undangan, kepala daerah menetapkan peraturan kepala daerah. $^{3}$

Untuk melaksanakan ketentuan Pasal 243 ayat (3) UU No. 23 Tahun 2014 yang mengatur mengenai tata cara pemberian nomor register peraturan daerah yang merupakan bagian dari pembentukan produk hukum daerah dan dinamika perkembangan peraturan perundang-undangan mengenai produk hukum daerah ditetapkan Peraturan Menteri Dalam Negeri Nomor 80 Tahun 2015 tentang Produk Hukum Daerah (Permendagri No. 80 Tahun 2015). ${ }^{4}$

Ketentuan dalam Pasal 87 ayat (2) Peraturan Menteri Dalam Negeri Republik Indonesia (Permendagri) Nomor 80 Tahun 2015 tentang Pembentukan Produk Hukum Daerah ditegaskan, bahwa "pembinaan terhadap rancangan produk hukum daerah berbentuk peraturan di Kabupaten/Kota dilakukan oleh Gubernur." Pembinaan terhadap rancangan produk hukum daerah dilakukan dalam bentuk fasilitasi. Hal tersebut ditegaskan dalam ketentuan Pasal 88 ayat (1) Permendagri No. 80 Tahun 2015 bahwa, "pembinaan sebagaimana dimaksud dalam Pasal 87 dilakukan fasilitasi terhadap rancangan Perda sebelum mendapat persetujuan bersama antara Pemerintah Daerah dan DPRD."

Terhadap rancangan produk hukum daerah yang berbentuk rancangan Perda sebelum ditetapkan wajib mendapatkan nomor register dari Menteri Dalam Negeri untuk rancangan Perda Provinsi dan dari Gubernur untuk rancangan Perda Kabupaten/Kota. ${ }^{5}$ Jika belum mendapatkan nomor register maka rancangan Perda tersebut belum dapat

\footnotetext{
Pasal 246 ayat (1) UU No. 23 Tahun 2014.

Konsideran Menimbang Permendagri No. 80 Tahun 2015.

5 Lihat Pasal 100 ayat (1) dan ayat (2) Permendagri No. 80 Tahun 2015.
} 
ditetapkan oleh kepala daerah dan belum dapat diundangkan dalam lembaran daerah. ${ }^{6}$

Dari ketentuan UU No. 23 Tahun 2014 dan Permendagri No. 80 Tahun 2015 tersebut di atas, maka dalam pembentukan produk hukum daerah khususnya Perda di Kabupaten/Kota terdapat 2 (dua) fungsi Gubernur sebagai prosedur dalam pembentukan Perda, yaitu:

1. fungsi fasilitasi rancangan Perda sebelum mendapat persetujuan bersama antara Bupati/Walikota dengan DPRD; dan

2. pemberian nomor register rancangan Perda Kabupaten/Kota sebelum ditetapkan oleh Bupati/Walikota dan diundangkan dalam lembaran daerah.

Dalam penyelenggaraan pemerintahan daerah di Provinsi Sulawesi Tenggara menunjukkan adanya pelanggaran prosedur mekanisme fasilitasi rancangan Perda dan adanya tindakan Kepala Daerah yang menetapkan sebuah Perda dan bahkan melaksanakan ketentuan Perda tersebut, sebelum ada nomor register dari Gubernur. ${ }^{7}$ Padahal ketentuan Pasal 243 ayat (1) UU No. 23 Tahun 2014 bahwa "rancangan Perda yang belum mendapat nomor register sebagaimana dimaksud dalam Pasal 242 ayat (5) belum dapat ditetapkan kepala daerah dan belum dapat diundangkan dalam lembaran daerah", serta ketentuan Pasal 87 ayat (1) Permendagri No. 80 Tahun 2015 menegaskan, bahwa "pembinaan sebagaimana dimaksud dalam Pasal 87 dilakukan fasilitasi terhadap rancangan Perda sebelum mendapat persetujuan bersama antara Pemerintah Daerah dan DPRD." Selain itu, dari 17 (tujuh belas) Kabupaten/Kota di Provinsi Sulawesi Tenggara baru sekitar 40\% (empat puluh persen) yang mengajukan Produk hukum Daerah bahkan dapat dikatakan hampir tidak ada produk hukum daerah berbentuk rancangan Perkada, PB Kepala Daerah dan rancangan peraturan DPRD yang dimintakan fasilitasi oleh kabupaten/kota. ${ }^{8}$

6 Lihat Pasal 103 Permendagri No. 80 Tahun 2015.

7 Salah satu kejadian adalah penetapan Perda tentang pembentukan kecamatan di Kota Kendari oleh Walikota Kendari sebelum ada nomor register dari Gubernur. Sumber Biro Hukum Setda Provinsi Sulawesi Tenggara, Juni 2018.

8 Sumber Biro Hukum Sekretariat Daerah Provinsi Sulawesi Tenggara, Juni 2018. 


\section{ANALISIS DAN PEMBAHASAN}

\section{Kedudukan Hukum Fasilitasi Produk Hukum Daerah}

\section{Konsep Desentralisasi Dalam Otonomi Daerah}

Secara etimologis istilah desentralisasi berasal dari bahasa Latin, yaitu: "de" = lepas dan "centrum" = pusat. Jadi menurut perkataannya desentralisasi itu ialah melepaskan dari pusat. ${ }^{9}$ Amrah Muslimin menyebutkan, bahwa desentralisasi ialah pelimpahan kewenangan pada badan-badan dan golongan-golongan dalam masyarakat dalam daerah tertentu untuk mengurus rumah tangganya sendiri. ${ }^{10} \mathrm{Amrah}$ Muslimin membagi desentralisasi menjadi: 1) Desentralisasi politik, 2) Desentralisasi fungsional, 3) Desentralisasi kebudayaan (culturele decentralisatie),

Menurut UU No. 23 Tahun 2014, desentralisasi adalah penyerahan urusan pemerintahan oleh pemerintah pusat kepada daerah otonom berdasarkan asas otonomi. ${ }^{11}$

Merujuk pada pandangan-pandangan tersebut di atas, maka NKRI yang memiliki wilayah yang luas, perlu diselenggarakan pemerintahan dengan sistem desentralisasi demi efisiensi, efektivitas, dan demokratisasi penyelenggaraan pemerintahan. Ini berarti bahwa rakyat di daerah diikutsertakan untuk menyelenggarakan sebagian urusan pemerintahan menurut kepentingannya berdasarkan inisiatif dan kebijaksanaan sendiri.

Sehingga dapat disimpulkan bahwa otonomi daerah adalah bagian atau salah satu bentuk dari desentralisasi dengan adanya penyerahan atau pelimpahan urusan pemerintahan dari pemerintah kepada suatu tingkat daerah tertentu untuk diatur dan diurus sebagai urusan rumah tangga sendiri.

\section{Ajaran Rumah Tangga Daerah}

Dalam pelaksanaan dan penyelenggaraan pemerintahan disetiap negara, terdapat berbagai urusan di daerah. Suatu urusan tetap menjadi urusan Pemerintah Pusat dan urusan lain menjadi urusan rumah tangga daerah sendiri, sehingga harus ada pembagian yang jelas. Dalam rangka melaksanakan cara pembagian urusan dikenal adanya sistem otonomi yang dikenal sejak dulu, yakni cara pengisian rumah tangga daerah atau sistem rumah tangga daerah.

\footnotetext{
9 R.D.H. Koesoemahatmadja. Pengantar Ke Arah Sistem Pemerintahan Daerah Di Indonesia, Bandung: Bina Cipta, 1979, hlm. 14.

10 Amrah Muslimin, Aspek-Aspek Hukum Otonomi Daerah, Bandung: Alumni, 1978, hlm. 15.

11 Pasal 1 angka 8 UU No. 23 Tahun 2014.
} 
Sistem rumah tangga daerah adalah tatanan yang bersangkutan dengan cara-cara membagi wewenang, tugas dan tanggung jawab mengatur dan mengurus urusan pemerintahan antara Pusat dan Daerah. Jadi menurut ajaran rumah tangga material, untuk mengetahui yang manakah urusan pemerintahan itu termasuk urusan rumah tangga daerah atau pusat harus melihat kepada materi yang akan diatur dan diurus oleh satuan pemerintahan itu masing-masing. Sehingga dengan melihat kepada materinya, maka orang sudah dapat membedakan bahwa suatu urusan itu termasuk urusan pemerintah daerah atau urusan pemerintah pusat. ${ }^{12}$

Dalam sistem rumah tangga formal tidak secara a priori ditetapkan apa yang termasuk urusan rumah tangga daerah itu. Tugas dari daerah-daerah tidak dirinci secara nominatif di dalam undang-undang pembentukannya, melainkan ditentukan dalam suatu rumus umum saja.Dengan demikian, dalam sistem rumah tangga formal pada prinsipnya daerah boleh mengatur dan mengurus segala sesuatu urusan rumah tangga daerah atas inisiatif dan kebebasan sendiri, meskipun urusan tersebut belum diserahkan oleh pusat.

Unsur sistem rumah tangga formal tercermin dari kebebasan daerah dalam mengatur segala sesuatu urusan pemerintahan yang dianggap penting bagi daerahnya dengan pembatasan-pembatasan tertentu. Sedangkan unsur sistem rumah tangga material tampak dari adanya urusan pangkal yang diserahkan pada saat pembentukan suatu daerah otonom.

\section{Konsep Hukum Fasilitasi Rancangan Peraturan Daerah}

Pengertian konsep hukum yakni konsep konstruktif dan sistematis yang digunakan untuk memahami suatu aturan hukum atau sistem aturan hukum, misalnya konsep-konsep hak, kewajiban, perjanjian, perikatan, sah, batal, subjek hukum, objek hukum dan sebagainya.

Fasilitasi rancangan Perda adalah tindakan pembinaan berupa pemberian pedoman dan petunjuk teknis, arahan, bimbingan teknis, supervisi, asistensi dan kerja sama serta monitoring dan evaluasi yang dilakukan oleh Menteri Dalam Negeri kepada provinsi serta Menteri Dalam Negeri dan/atau gubernur kepada kabupaten/kota terhadap materi muatan rancangan produk hukum daerah berbentuk peraturan sebelum ditetapkan guna menghindari dilakukannya pembatalan. ${ }^{13}$ Dengan demikian menurut

\footnotetext{
12 Moh. Kusnardi dan Harmaily Ibrahim. Pengantar Hukum Tata Negara Indonesia, Pusat Studi Hukum Tata Negara Fakultas Hukum Universitas Indonesia dan Sinar Bakti, Jakarta, 1988, hlm. 254.

13 Pasal 1 angka 24 Permendagri No. 80 Tahun 2015.
} 
peneliti, konsep hukum Fasilitasi rancangan Perda adalah konsep konstruktif dan sistematis yang digunakan untuk memahami aturan fasilitasi rancangan Perda.

Dengan demikian dapat dikatakan bahwa, konsep hukum fasilitasi rancangan Perda merupakan bentuk pembinaan Pemerintah Pusat terhadap Daerah dalam membentuk produk hukum daerah agar tidak bertentangan dengan peraturan perundang-undangan yang lebih tinggi dan kepentingan umum.

\section{Peraturan Daerah Sebagai Produk Hukum Daerah}

Perda adalah produk hukum yang sifatnya adalah peraturan perundang-undangan dengan sifat norma hukumnya adalah dauerhafting, yakni norma hukum yang berlaku terus menerus dalam jangka waktu yang tidak terbatas sampai dicabut atau diganti yang baru. Berbeda halnya dengan produk hukum yang sifatnya penetapan sifat norma hukumnya adalah einmalig, yakni norma hukum yang berlaku sekali saja dan sifatnya hanya menetapkan inilah yang disebut dengan keputusan/ketetapan administrasi negara.

Sebagai elemen dari peraturan perundang-undangan, maka Perda secara otomatis tidak boleh berdiri sendiri. Perda harus menyandarkan pengaturannya pada peraturan perundang-undangan yang lebih tinggi (verordnung \& autonome satzung). Sebagaimana diketahui, bahwa Perda adalah peraturan perundang-undangan yang dibentuk oleh DPRD dengan persetujuan bersama Kepala Daerah yang materi muatannya untuk penyelenggaraan otonomi daerah dan tugas pembantuan serta menampung kondisi khusus daerah dan/atau penjabaran lebih lanjut peraturan perundang-undangan yang lebih tinggi.

\section{Keberlakuan Rancangan Peraturan Daerah Tanpa Fungsi Fasilitasi}

\section{Teori Keberlakuan Hukum}

Kekuasaan membentuk undang-undang biasanya dipegang oleh lembaga legislatif atau yang populer disebut parlemen. Parlemen ini merupakan lembaga perwakilan rakyat yang merupakan penjelmaan seluruh rakyat yang berdaulat. Lembaga perwakilan rakyat atau parlemen memegang mandat sebagai lembaga legislatif dan pengontrol jalannya

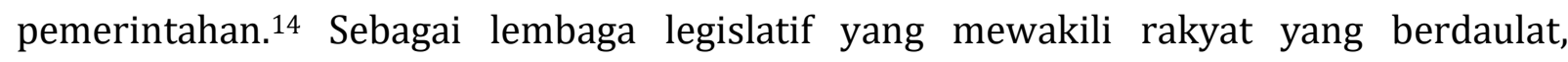

\footnotetext{
14 Jimly Asshiddiqie. Hukum Tata Negara Darurat, Jakarta: RajaGrafindo Persada, 2007, hlm. 259.
} 
parlemenlah yang merupakan pemegang kekuasaan untuk membentuk undang-undang (legislator). ${ }^{15}$

Dalam rangka itu pembentukan Undang-Undang pada dasarnya dimaksudkan untuk membatasi kekuasaan pemerintahan secara tegas dan jelas. Pada sisi lain pembentukan Undang- Undang dimaksudkan untuk melindungi hak-hak dasar. kedudukan Undang-Undang menjadi sangat strategis dalam implementasi ide negara hukum. Kesalahan dalam implementasi dapat menjadikan negara hukum sekedar sebagai suatu negara aturan atau negara Undang-Undang.

Peraturan perundang-undangan sebagai produk hukum dibuat dengan maksud untuk dipatuhi oleh masyarakat atau dengan kata lain untuk efektif atau hukum tersebut berperan sesuai fungsinya. Dalam teori hukum, berlakunya hukum sebagai kaidah didasarkan ada tiga anggapan, yaitu:

1) Kaidah hukum berlaku secara yuridis

2) Kaidah hukum berlaku secara sosiologis,

3) Kaidah hukum berlaku secara filosofis.

Agar hukum dapat berlaku, maka harus memenuhi ketiga unsur tersebut di atas, disebabkan karena:

1. Bila hukum berlaku secara yuridis, maka kemungkinan besar kaidah tersebut merupakan kaidah mati (dode regel).

2. Kalau hukum berlaku secara sosiologis (maka mungkin hukum berlaku dalam arti teori kekuasaan), maka kaidah tersebut menjadi aturan memaksa,

3. Apabila hanya berlaku secara filosofis, maka mungkin hukum tersebut hanya merupakan hukum yang dicita-citakan (ius constituendum). ${ }^{16}$

Berdasarkan uraian di atas, hukum yang dibuat dengan hasilnya dapat berlaku apabila dasar pemikiran yang mendasari adalah yuridis, sosiologis, dan filosofis.

\section{Teori Khirarki Norma}

Dalam keberlakuan hukum, Hans Kelsen mengemukakan, setiap tata kaidah hukum merupakan suatu susunan daripada kaidah-kaidah (stufenbau des rechts) dipuncak stufenbau terdapat kaidah dasar dari suatu tata hukum nasional yang merupakan kaidah

15 Ibid.

16 Soerjono Soekanto, Kegunaan Sosiologi Hukum Bagi Kalangan Hukum, Cetakan I, Bandung: Alumni, 2007, hlm. 47. 
fundamental. Kaidah dasar tersebut disebut grundnorm atau ursprungnorm. Grundnorm merupakan asas-asas hukum yang bersifat abstrak, umum atau hipotesis, kemudian bergerak ke generallenorm (kaidah umum), yang selanjutnya dipositifkan menjadi norma nyata (concretenorm). ${ }^{17}$

Hans Kelsen membagi konstitusi dalam dua pengertian materiil dan formal. Konstitusi dalam pengertian materiil adalah peraturan-peraturan yang mengatur pembentukan norma-norma hukum yang bersifat umum khususnya pembentukan undang-undang. Konstitusi dalam pengertian formal adalah suatu dokumen resmi, seperangkat norma hukum yang dapat diubah hanya di bawah pengawasan ketentuanketentuan khusus, yang tujuannya adalah untuk membuat perubahan norma-norma itu lebih sulit. Sulitnya perubahan dari peraturan-peraturan konstitusi dari pengertian formal tersebut dimaksudkan untuk melindungi norma-norma yang menentukan organ-organ dan prosedur pembentukan undang-undang.

\section{Teori Penjenjangan Norma}

Teori Hans Kelsen tersebut kemudian dikembangkan oleh Hans Nawiasky (muridnya). Menurut Hans Nawiasky, norma-norma hukum dalam negara selalu berjenjang, yakni sebagai berikut:

1. Norma fundamental negara (staatsfundamentalnorm);

2. Aturan-aturan dasar negara/aturan pokok negara (staatsgrundgesetz);

3. Undang-undang (formal) (formell gesetz); dan

4. Peraturan pelaksanaan serta peraturan otonom (verordnung \& autonome satzung).

Apabila hierarki diberlakukan dalam peraturan perundang-undangan dalam desain teori Nawiasky tersebut pada paragraf di atas, dilihat dalam perspektif hukum positif di Indonesia, maka menurut ketentuan Pasal 7 ayat (1) Undang-Undang Nomor 12 Tahun 2011 tentang Pembentukan Peraturan Perundang-Undangan (UU No. 12 Tahun 2011), jenis hierarki peraturan perundang-undangan terdiri atas:

a. Undang-Undang Dasar Negara Republik Indonesia Tahun 1945;

b. Ketetapan Majelis Permusyawaratan Rakyat;

c. Undang-Undang/Peraturan Pemerintah Pengganti Undang-Undang;

17 Rosjidi Ranggawidjaja, Pengantar Ilmu Perundang-Undangan Indonesia, Bandung: Mandar Maju, 1998, hlm. 26. 
d. Peraturan Pemerintah;

e. Peraturan Presiden;

f. Peraturan Daerah Provinsi; dan

g. Peraturan Daerah Kabupaten/Kota.

Hierarki peraturan perundang-undangan di Indonesia yang tertuang dalam ketentuan Pasal 7 ayat (1) UU No. 12 Tahun 2011 tersebut di atas, disusun secara berjenjang (piramidal) dengan fungsi sebagai tolok ukur bagi peraturan perundangundangan yang ada di bawahnya terhadap peraturan perundang-undangan yang ada di atasnya. adanya tata urutan (hierarki) peraturan perundang-undangan yang berjenjang.

\section{Teori Pengawasan}

Dalam menyelenggarakan pemerintahan, pemerintah mempunyai keleluasaan demi terselenggaranya kesejahteraan masyarakat tanpa meninggalkan asas legalitas. Hal ini berarti bahwa sikap tindak haruslah dapat dipertanggungjawabkan, baik secara moral maupun secara hukum. Oleh karena dengan adanya keleluasaan bertindak dari pemerintah yang memasuki semua sektor kehidupan masyarakat, kadang-kadang dapat menimbulkan kerugian bagi masyarakat itu sendiri. Maka, diadakan pengawasan terhadap jalannya pemerintahan.

Dalam kepustakaan, cara-cara pengawasan dalam penyelenggaraan pemerintahan dapat dirinci sebagai berikut :

1. Ditinjau dari segi kedudukan badan / organ yang melaksanakan pengawasan :

2. Ditinjau dari segi saat / waktu dilaksanakannya

3. Pengawasan dari segi hukum.

Pengawasan merupakan tindakan yang dimaksudkan untuk mencegah kemungkinan terjadinya penyimpangan tugas pemerintahan sebagaimana dasar-dasarnya diatur dalam konstitusi dan jabarannya diatur dalam undang-undang. ${ }^{18}$

Terhadap rancangan Perda hasil fasilitasi yang sudah ditindaklanjuti oleh Pemerintah Daerah untuk penyempurnaan, Bupati/Walikota wajib menyampaikan rancangan Perda Kabupaten/Kota kepada Gubernur sebagai wakil Pemerintah Pusat paling lama 3 (tiga) hari terhitung sejak menerima rancangan Perda Kabupaten/Kota dari

18 Suriansyah Murhani, Aspek Hukum Pegawasan Pemerintah Daerah, Yogyakarta: Laksbang Mediatama, 2008, hlm. 2. 
pimpinan DPRD kabupaten/kota untuk mendapatkan nomor register (noreg) Perda. ${ }^{19}$ Gubernur sebagai wakil Pemerintah Pusat memberikan noreg rancangan Perda Kabupaten/Kota paling lama 7 (tujuh) hari sejak rancangan Perda diterima. ${ }^{20}$

Mekanisme fasilitasi tersebut dapat digambarkan di bawah ini:

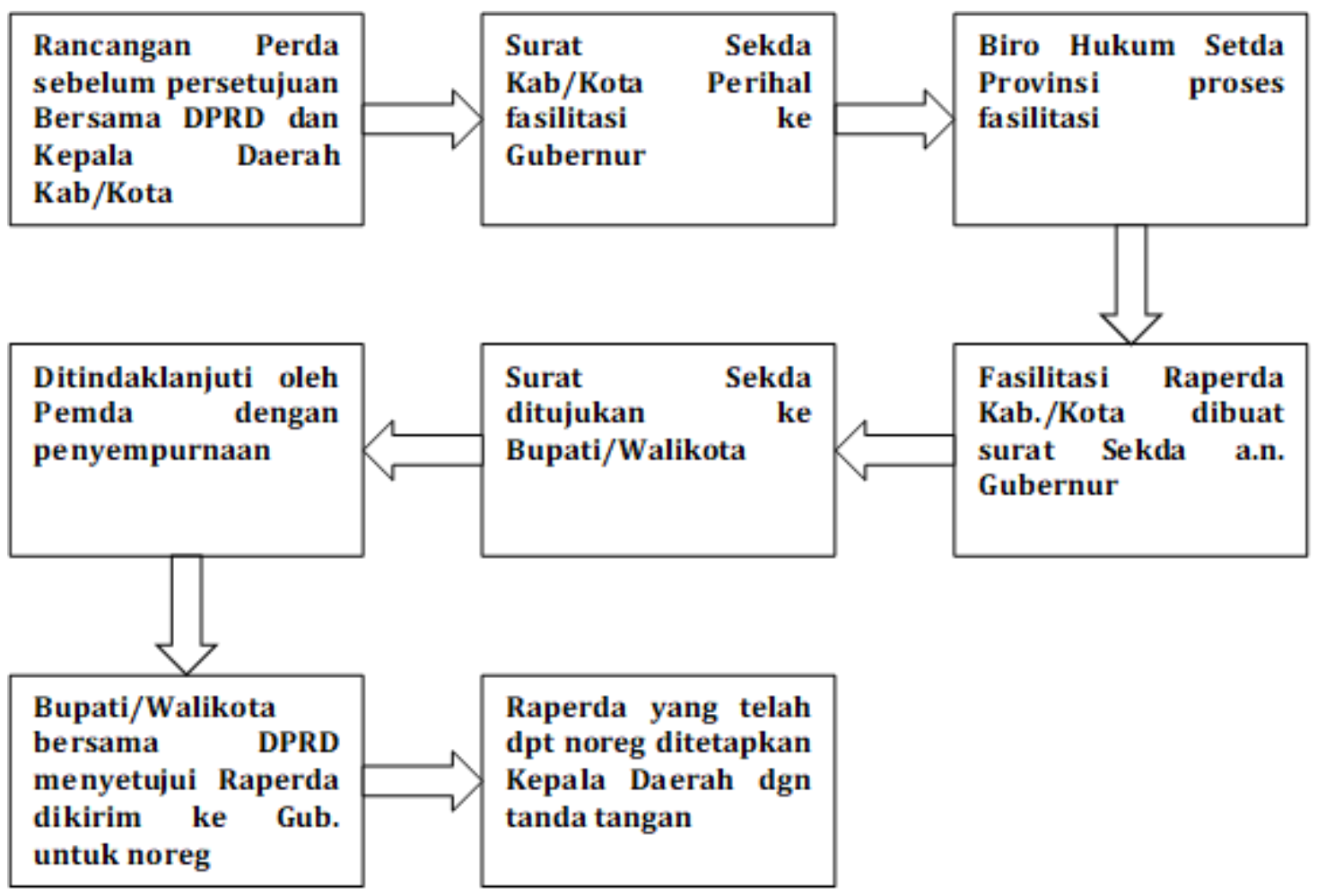

Gambar 1: Sumber: Peneliti berdasarkan Permendagri No. 80 Tahun 2015.

Menurut Hans Kelsen bahwa norma-norma hukum itu berjenjang-jenjang dan berlapislapis dalam suatu hierarki (tata susunan), dalam arti suatu norma yang lebih rendah berlaku dan berdasar pada norma yang lebih tinggi, norma yang lebih tinggi berlaku, bersumber dan berdasar pada norma yang lebih tinggi lagi, demikian seterusnya sampai pada suatu norma yang tidak dapat ditelusuri lebih lanjut dan bersifat hipotetis dan fiktif yaitu norma dasar (grundnorm).21

19 Pasal 100 ayat (2) Permendagri No. 80 Tahun 2015.

20 Pasal 102 ayat (1) Permendagri No. 80 Tahun 2015.

21 Maria Farida Indrati S. Ilmu Perundang-Undangan, Jenis, Fungsi, dan Materi Muatan, Yogyakarta: Kanisius, 2007, hlm. 41. 


\section{Prosedur Fasilitasi Rancangan Peraturan Daerah Kabupaten/Kota Berdasarkan Peraturan Perundang-Undangan}

Pembentukan rancangan Perda adalah suatu program pembentukan rancangan peraturan perundang-undangan di Daerah yang terdiri dari rancangan Perda yang didasarkan atas usul Pemerintah Daerah atau Dewan Perwakilan Rakyat Daerah (DPRD). Rancangan Perda di bentuk berdasarkan urgensi dan prioritas dalam penyelenggaraan pemerintahan daerah.

Berdasarkan ketentuan tersebut di atas, Perda merupakan bagian dari jenis dan hierarki peraturan perundang-undangan. Pembentukan peraturan perundang-undangan adalah pembuatan peraturan perundang-undangan yang mencakup tahapan perencanaan, penyusunan, pembahasan, pengesahan atau penetapan, dan pengundangan. ${ }^{22}$ Oleh karena itu dalam pembentukan rancangan Perda harus melalui tahapan sesuai dengan UU No. 12 Tahun 2011.

Tahapan pembentukan Perda di Kabupaten/Kota adalah: 1. Perencanaan penyusunan Perda dilakukan dalam program legislasi daerah 2. Penyusunan Rancangan Perda Kabupaten/Kota dapat berasal dari DPRD Kabupaten/Kota atau Bupati/Walikota 3. Pembahasan rancangan Perda Kabupaten/Kota dilakukan oleh DPRD Kabupaten/Kota bersama Bupati/Walikota 4. Pengesahan atau Penetapan Rancangan Perda Kabupaten/Kota yang telah disetujui bersama oleh DPRD Kabupaten/Kota dan Kepala Daerah disampaikan oleh pimpinan DPRD kepada Kepala Daerah untuk ditetapkan menjadi Perda Kabupaten/Kota 5. Pengundangan Perda diundangkan dalam Lembaran Daerah. $^{23}$

Terhadap rancangan Perda hasil fasilitasi yang sudah ditindaklanjuti oleh Pemerintah Daerah untuk penyempurnaan, Bupati/Walikota wajib menyampaikan rancangan Perda Kabupaten/Kota kepada Gubernur sebagai wakil Pemerintah Pusat paling lama 3 (tiga) hari terhitung sejak menerima rancangan Perda Kabupaten/Kota dari pimpinan DPRD kabupaten/kota untuk mendapatkan nomor register (noreg)Perda. ${ }^{24}$

Pasal 1 angka 1 UU No. 12 Tahun 2011.

23 Pasal 86 ayat (1) UU No. 12 Tahun 2011.

24 Pasal 100 ayat (2) Permendagri No. 80 Tahun 2015. 


\section{Keberlakuan Fasilitasi Rancangan Peraturan Daerah Dalam Pembentukan Peraturan Daerah}

Berdasarkan ketentuan Pasal 1 angka 8 UU No. 12 Tahun 2011 yang dimaksud dengan "Peraturan Daerah Kabupaten/Kota adalah Peraturan Perundang-undangan yang dibentuk oleh Dewan Perwakilan Rakyat Daerah Kabupaten/Kota dengan persetujuan bersama Bupati/Walikota". Peraturan daerah dibuat oleh Pemerintah Daerah dalam rangka untuk menjalankan otonomi daerah dalam Negara kesatuan Republik Indonesia.

Adapun lingkup wewenang membentuk Perda ditentukan bahwa Perda mengatur urusan rumah tangga di bidang otonomi dan urusan rumah tangga di bidang tugas pembantuan. Di bidang otonomi, Perda dapat mengatur segala urusan pemerintah dan kepentingan masyarakat yang tidak diatur oleh Pemerintah Pusat. Di bidang pembantuan, Perda tidak mengatur substansi urusan pemerintah atau kepentingan masyarakat. Perda di bidang pembantuan hanya mengatur tata cara melaksanakan substansi urusan pemerintah atau kepentingan masyarakat. ${ }^{25}$

Jimly Ashiddiqie berpendapat bahwa dalam rangka reformasi ke arah perwujudan cita-cita negara yang berparadigma atau berwawasan hukum, maka hukum dan sistem hukum itu sendiri juga perlu direformasi terlebih dulu. Secara simultan diikuti oleh reformasi politik, reformasi ekonomi, dan reformasi sosial budaya. Dalam kenyataannya, reformasi hukum itulah yang bersifat instrumental dalam rangka perwujudan gagasan reformasi politik, sosial, dan ekonomi.

Perda pada hakikatnya merupakan bagian yang tidak terpisahkan dari kesatuan sistem peraturan perundang-undangan secara nasional. Oleh sebab itu tidak boleh ada Perda yang bertentangan dengan peraturan perundang-undangan yang lebih tinggi, kepentingan umum dan kesusilaan. Dalam kondisi yang demikian inilah maka kedudukan Perda merupakan sub sistem peraturan perundang-undangan nasional.

\section{KESIMPULAN}

Berdasarkan pada uraian pembahasan yang telah dikemukakan di atas, peneliti dapat simpulkan beberapa hal, yaitu:

1. Kedudukan Hukum mengikat terhadap Rancangan Perda tanpa melalui prosedur fasilitasi dalam pembentukan produk hukum daerah tidak sesuai

\footnotetext{
25 Bagir Manan, op. cit., hlm. 72.
} 
dengan ketentuan peraturan perundang-undangan dalam hal ini UU No. 23 Tahun 2014.karena prosedur fasilitasi merupakan bagian dari prosedur dalam pembentukan rancangan Perda sebagaimana dimaksud dalam UU No. 23 Tahun 2014. Sehingga dalam pembentukan rancangan Perda harus melewati prosedur fasilitasi sebagai pedoman dalam pemberian nomor register rancangan Perda sebelum ditetapkan oleh Kepala Daerah dan diundangkan oleh Sekretaris Daerah.

2. Keberlakuan fasilitasi Rancangan Peraturan Daerah Dalam Pembentukan Peraturan daerah tanpa prosedur fasilitasi dapat dilakukan pembinaan dengan cara penundaan pemberian Nomor Registrasi Perda.

\section{Daftar Pustaka}

\section{Buku}

Asshiddiqie, Jimly. Hukum Tata Negara Darurat, Jakarta: RajaGrafindo Persada, 2007.

Koesoemahatmadja, R.D.H.. Pengantar Ke Arah Sistem Pemerintahan Daerah Di Indonesia, Bandung: Bina Cipta, 1979.

Kusnardi, Moh. dan Harmaily Ibrahim. Pengantar Hukum Tata Negara Indonesia, Pusat Studi Hukum Tata Negara Fakultas Hukum Universitas Indonesia dan Sinar Bakti, Jakarta, 1988.

Manan, Bagir, Hubungan Antara Pusat dan Daerah Menurut UUD 1945, Jakarta: Pustaka Sinar Harapan, 1994.

Murhani, Suriansyah, Aspek Hukum Pegawasan Pemerintah Daerah, Yogyakarta: Laksbang Mediatama, 2008.

Muslimin, Amrah, Aspek-Aspek Hukum Otonomi Daerah, Bandung: Alumni, 1978.

Ranggawidjaja, Rosjidi, Pengantar Ilmu Perundang-Undangan Indonesia, Bandung: Mandar Maju, 1998.

S, Maria Farida Indrati Ilmu Perundang-Undangan, Jenis, Fungsi, dan Materi Muatan, Yogyakarta: Kanisius, 2007.

Soekanto, Soerjono, Kegunaan Sosiologi Hukum Bagi Kalangan Hukum, Cetakan I, Bandung: Alumni, 2007.

\section{Peraturan Perundang-undangan}

Undang-Undang Dasar Negara Republik Indonesia Tahun 1945. 
Undang-Undang Nomor 12 Tahun 2011 tentang Pembentukan Peraturan Perundangundangan (Lembaran Negara Republik Indonesia Tahun 2011 Nomor 82, Tambahan Lembaran Negara Republik Indonesia Nomor 5234).

Undang-Undang Nomor 23 Tahun 2014 tentang Pemerintahan Daerah (Lembaran Negara Republik Indonesia Tahun 2014 Nomor 244, Tambahan Lembaran Negara Republik Indonesia Nomor 5587) sebagaimana telah diubah beberapa kali terakhir dengan Undang-Undang Nomor 9 Tahun 2015 tentang Perubahan Kedua Atas UndangUndang Nomor 23 Tahun 2014 tentang Pemerintahan Daerah (Lembaran Negara Republik Indonesia Tahun 2014 Nomor 58, Tambahan Lembaran Negara Republik Indonesia Nomor 5679).

Peraturan Menteri Dalam Negeri Nomor 80 Tahun 2015 tentang Pembentukan Produk Hukum Daerah (Berita Negara Republik Indonesia Tahun 2015 Nomor 2036). 